\title{
Příspěvek k teorii kulturní paměti (kanonizace národních básníků)
}

\author{
Miloš Zelenka (České Budějovice)
}

Marijan Dović: Prešeren po Prešernu. Kanonizacija nacionalnega pesnika in kulturnega svetnika. Ljubljana: Literarno-umetniško društvo Literatura, 2017. 344 s. ISBN 978-961-7017-04-5.

Lublaňský badatel Marijan Dović z Ústavu slovinské literatury a literární vědy ZRC SAZU v letech 2014-2017 realizoval ve spolupráci s holandským komparatistou a kulturním antropologem Joepem Leerssenem projekt National Poets and Cultural Saints of Europe. Commemorative Cults, Canonization, and Cultural Memoary, který si kladl za cíl přesněji identifikovat jádro kulturní tradice, resp. popsat a vysvětlit transformační mechanizmy kanonizace a „uctívání“ spisovatelů v procesu sociální mobility moderních společností v letech 1840-1940. Projekt byl zároveň součástí mezinárodního programu pod názvem Encyclopedia of Romantic Nationalism in Europe, zahájeného roku 2010, který s využitím technologických možností soudobé digitální humanistiky zpřístupňuje komplexní univerzum evropského romantického nacionalismu $\mathrm{v}$ jeho disperzních variantách a tím umožňuje relativní dostupnost klíčových, statisticko-faktografických dat pro srovnávací studium evropských literárních kultur v 19. a 20. století. Z projektu byly publikovány četné časopisecké a knižní výstupy, mezi nimiž přední místo zaujímá syntetizující monografie Marijana Doviće Prešeren po Prešernu. Kanonizacija nacionalnega pesnika in kulturnega svetnika (2017). Její autor se vedle tzv. ingresivní literární historie zformulované J. Neubauerem a M. Cornisem-Popem inspiruje především impulzy postmoderní kulturní antropologie: větší důraz totiž klade na "posthumní život" materializovaných či textových projevů kultury v procesu jejich intenzivního osvojování a působení. Vytváří se tak specifický terminologicko-sémantický soubor pravidel reflektující „kulturní gramatiku“ každé společnosti, v níž se objevuje pozice „národní ikony“ (J. Neubauer).
Rozsáhlá monografie obsahující celkem devět kapitol se rozpadá na dvě základní části: na teoreticko-metodologický oddíl Nacionalni in kulturni svetniki v evropskih literarnih kulturah (s. 13-105) a literárněhistorickou část Kanonizacija Franceta Prešerna v slovenski literarni kulturi (s. 107-310). Zatímco první část načrtává analytický model kanonizace jakýchsi „kulturních světcü“, který do jisté míry analogicky připomíná v křestanském kontextu formální proces svatořečení církevního světce v jeho „posmrtném životě“, druhá prakticky demonstruje tento proces na nejslavnějším slovinském básníku Prešernovi. Z českého pohledu je zde zajímavá osmá kapitola mapující vztah Prešerna k Máchovi v souvislosti s podobným průběhem ratifikace kanonického procesu. Dović analyzuje i slovinskou recepci Máchova básnického díla, které svou tajemností a romantickým uchopením metafyzického protikladu života a smrti rezonovalo v celém jihoslovanském prostoru. Sympaticky působí, že Dović se nespokojuje s dostupnou literaturou, podnikl totiž před několika lety studijní cestu do Prahy i míst spjatých s Máchovou osobností a pokusil se zachytit širokou škálu ritualizačních praktik jako třeba intertextuální návaznost, překlady, citace, ale i „stopy“ v názvech ulic, parků a v elementech materiální kultury jako jsou pomníky, sochy, muzea, rodné domky, zobrazení na mincích a bankovkách apod. K tomu připojil i formální ratifikační procedury jako třeba přítomnost v školském systému, čítankách, učebnicích apod. Obdobně, i když jen typologicky, Dović konfrontuje Prešerna $\mathrm{s}$ islandským básníkem Jónasem Hallgrímssonem, který je považován za zakladatele novodobé islandské poezie a prózy a který - stejně jako Prešeren a Mácha - se stal metaforickým symbolem své kultury bez ohledu na politické výkyvy. 
Dovićův analytický model kanonizace „kulturních světcü“ představuje složitý a mnohovrstevnatý proces studia kulturních „stop“ „pozůstatků“, „znaků“ v materializovaných či textových projevech kultur, které zůstaly přítomny ve vědomí jednotlivců i nejrůznějších skupin. Nejde tu jen o registraci literární, čistě slovesné metakomunikace, tj. o konkrétní interpretace textů a biografické sledování kariér, ale o komplexní analýzu časového paradigmatu, v němž se ocitá jistá vzpomínka jako součást nově vznikající literární tradice a kulturní paměti. Vzpomínka prochází mezigeneračním transferem a nachází se v čase mezi uložením a jednotlivou evokací, přičemž podléhá strukturním změnám. Pamět je tudíž podřízena časovému plynutí, nebot proces vzpomínání (ale i zapomínání) vedle mechanické reprodukce stop doplňuje produktivní aktivita, která minulost nahlíží pod zorným úhlem budoucnosti. Minulost se v podstatě nejen prožívá, ale i zároveň generuje např. formou variantních literárních obrazů.

Model kanonizace „kulturních světců“ se skládá ze tří strukturních, obsahově i časově provázaných komponentů: 1. vita (literární subjekt a jeho možnosti kanonizace), 2. cultus (kanonizace v užším smyslu) a 3. effectus (společenské konsekvence vyplývající z procesu kanonizace). Každá část je dále rozpracována na jednotlivé kategorie. $\mathrm{V}$ případě první části „život“, který zahrnuje potenciální souhrn kanonických možností fyzické osoby, jde o vysledování specifických biografických momentů implikujících obecně uznanou zvláštnost či výjimečnost literárního subjektu (persona, aenigma, opera, acta). Druhý oddíl analytického modelu kanonizace se rozčleňuje na produkci (proces vycházející z kanonizace primárního korpusu textů - skriptura) a reprodukci kanonizovaného statusu (kanonizace sekundárního korpusu textů - konfirmace), která může signalizovat např. „osvojení“ či „přivlastnění“ autora některými mocenskými skupinami ve smyslu indikátoru politické moci (např. „kulturní světec“ jako státní symbol). Poté mohou následovat rituály (např. odkrývání památníku), apropriace (vědecké a popularizující interpretace upevňující status „kulturního světce“), prokreativnost a indoktrinace (vznik her, scénářů, libret, imitací a eventuální integrace do školského systému). Třetí část modelu Efekty zachycuje společenské důsledky konkrétního kultu, kdy napřr. se dovršuje sémiotická nacionalizace veřejného prostoru. Jedná se tu především o výzkum sociálních rámců a kulturních podmínek, za nichž se pozice „kulturního světce“ institucionalizuje prostřednictvím topografie a geografie ve veřejném a mediálním kontextu.

Dovićova monografie založená na analytickém konceptu „kulturních světcü“ interdisciplinárně obohacuje klasickou literární historii o novou dimenzi. Rozšiřuje tradiční teorii kánonu převážně syntagmaticky chápaného jako dynamickou konfiguraci posttextových vztahů. Sociologické studium literární tradice jako korelátu a specifických modelů komunikačních výpovědí o životě a díle autora se tak modifikuje na rekonstrukci kritérií, jimiž členové určitého společenství vnášejí do kolektivní paměti odlišnost literárního výtvoru od jiných komunikátů. Ačkoli Dović model kanonizace vytvořil pomocí empirického souboru dat převážně prostřednictvím verifikovatelných údajů, jednotlivé kategorie vznikly na základě dlouhodobého historického výzkumu moderních evropských kultur. Sběr dat realizovali vždy badatelé, kteří žili „uvnitř“ daného společenství a kteří dospěli k zobecnění, tak i k subjektivní intimní zkušenosti, jak nazírat vlastní kulturní dědictví.

Podle našeho názoru se koncept „kulturních světcü“ sbližuje i s Foucaultovou literární archeologií (i přesto, že Dović k foucaultovským inspiracím neodkazuje) v tom smyslu, že i zde se klade důraz na rekonstrukci diskurzní praxe uměleckých výtvorů. Zároveň studium materiální dimenze znakových stop oscilujících mezi institucemi a texty připomíná i Greenblattův tzv. nový historismus - konkretizuje totiž tolik exploatovaný model literárního kánonu vztažený mylně jen k textové kanonizaci. Přínos Dovićovy monografie spočívá v tom, že přesně popsala při generování „velkých“ osobností textové a mimotextové praktiky, které podléhají přes- 
ným pravidlům, ale i chaosu a nahodilosti. Tím estetická hodnota, jazyk či reduktivní parafráze je možné lépe pochopit, proč o kanonizaci ja- hlavní „ideje“, ale i proces institucionalizace kéhokoliv literárního subjektu rozhoduje nejen a vnější historická situace národního kolektivu.

\section{prof. PhDr. Miloš Zelenka, DrSc.}

Katedra slovanských jazyků a literatur

Pedagogická fakulta, Jihočeská univerzita

Jeronýmova 10, 37115 České Budějovice, Česká republika

zelenka@pf.jcu.cz 